\title{
Toxicity of Chlorantraniliprole and Lufenuron Against the Cotton Leafworm Larvae in Relation to Their Effects on AST, ALT and ALP Enzymes Activity
}

\author{
Saad $^{1}$, A. S. A., E. H. M. Tayeb ${ }^{1}$, Wafa H. Hegazy ${ }^{2}$ and \\ Ehsan M. Abdel-Moety ${ }^{2}$ \\ 1- Plant Protection Dept., Fac. Agric. (Saba Basha), Alex. Univ., P.O Box 21531-Bolkly, \\ Alex., Egypt \\ 2- Cotton Pesticides Evaluation Res., Plants Protection Res. Institute, Agriculture Res. \\ Center, Dokki, Giza, Egypt
}

\begin{abstract}
The toxicity of chlorantraniliprole (an anthranilic diamide) and lufenuron (an insect growth inhibitor) against the $2^{\text {nd }}$ and $4^{\text {th }}$ instar larvae of the cotton leafworm, Spodoptera littoralis (Boisd.) was investigated. The in vivo effects of chlorantraniliprole and lufenuron on the activity of each of aspartate aminotransferase (AST), alanine aminotransferase (ALT) and alkaline phosphatases (ALP) activities of the S. littoralis $4^{\text {th }}$ larval instar were also assessed. The bioassay of the $2^{\text {nd }}$ instar larvae revealed that chlorantraniliprole $\left(\mathrm{LC}_{50}=0.009,0.005\right.$ and $\left.0.003 \mathrm{mg} / \mathrm{l}\right)$ was approximately as $234.3,206.2$ and 226.3 fold more toxic than lufenuron $\left(\mathrm{LC}_{50}=2.019,1.031\right.$ and $0.679 \mathrm{mg} / \mathrm{l})$ after three different exposure periods (48, 72 and $96 \mathrm{hrs}$, respectively). Concerning the $4^{\text {th }}$ instar larvae, chlorantraniliprole $\left(\mathrm{LC}_{50}=6.645,0.028\right.$ and $\left.0.006 \mathrm{mg} / \mathrm{l}\right)$ was approximately as 2.01 , 105.36 and 226.3 fold more toxic than lufenuron $\left(\mathrm{LC}_{50}=13.37,2.95\right.$ and $1.87 \mathrm{mg} / \mathrm{l}$ ) after 48,72 and $96 \mathrm{hrs}$ of exposure, respectively. In vivo effect of chlorantraniliprole and lufenuron enhanced the activity of AST and ALT and that enhancement was concentration and time of exposure dependent. Both chlorantraniliprole and lufenuron inhibited ALP activity; which was also concentration and time of exposure dependent. Based on the obtained results, chlorantraniliprole and lufenuron would be involved within the current foliar insecticide applications used for controlling $S$. littoralis in cotton fields.
\end{abstract}

Keywords: Spodoptera littoralis, chlorantraniliprole, lufenuron.

\section{INTRODUCTION}

The cotton leafworm (CLW), Spodoptera littoralis (Boisd.) is one of the most destructive agriculture lepidopterous insect-pests. In Egypt, it can attack numerous economically important crops throughout the year (Hatem et al., 2009). The chemical control of $S$. littoralis has been extensively reported especially in relation to cotton in Egypt (Abo-El-Ghar et al., 1986). Extensive use of insecticides, multiple generations of CLW per annum and the availability of host crops, all over the year have contributed to the development of resistance in this insect-pest to many insecticide groups (Abo Elghar et al., 2005; Abou-Taleb, 2010). Therefore, searching for an effective alternatives and/or pest control strategies is needed to avoid the increase of the selection pressure of the insect population to insecticides and provide adequate crop protection for sustainable food, feed and crops of fiber production. This need is met in part by the insecticide chlorantraniliprole, which has a novel mechanism of action and can be applied as an alternative insecticide for managing CLW (Bentley et al., 2010).

Chlorantraniliprole is discovered by DuPont; it is also known as rynaxypyr (Bentley et al., 2010). Studies have shown that chlorantraniliprole has exceptional insecticidal activity on a range of lepidopteran pests and many other orders, such as Coleoptera, Diptera, Isoptera and Hemiptera (Sattelle et al., 2008; Lahm et al., 
2009). Chlorantraniliprole activates the unregulated release of internal calcium stores leading to $\mathrm{Ca}^{2+}$ depletion, feeding cessation, lethargy, muscle paralysis and finally insect death (Lahm et al., 2005). It blocks the feeding of lepidopteran larvae rapidly; the feeding cessation time being equivalent to that of nerve agents. Accordingly, it was ranked as the fastest-acting insecticide for lepidopteran control (Hannig et al., 2009). In addition, the low ecotoxicology to non-target organisms such as birds, fish, mammals, earthworms and many other arthropods (Lahm et al., 2007; Larson et al., 2012) and no cross-resistance with other older classes of chemistry (Cao et al., 2010; Sial et al., 2010; Wang et al., 2010) make it an excellent pest management tool.

It is critically important to establish the susceptibility of insects to newly developed insecticides before their widespread use. Therefore, the aim of this work was to assess the insecticidal activity of chlorantraniliprole compared to lufenuron against the $2^{\text {nd }}$ and $4^{\text {th }}$ larval instars (laboratory strain) of the cotton leafworm. The in vivo effects of chlorantraniliprole and lufenuron on certain enzymes activities [aspartate aminotransferase (AST), alanine aminotransferase (ALT) and alkaline phosphatases (ALP)] of the $4^{\text {th }}$ instar larvae of the cotton leafworm (laboratory strain) were also investigated.

\section{MATERIALS AND METHODS Experimental insect:}

A laboratory strain of the cotton leafworm, Spodoptera littoralis larvae used for testing the evaluated insecticides was reared under the laboratory conditions of $25 \pm 2{ }^{\circ} \mathrm{C}$ and $65 \pm 5 \% \mathrm{RH}$ according to Eldefrawi et al. (1964).

\section{Tested insecticides:}

Chlorantraniliprole (Coragen ${ }^{\circledR} 20 \%$ SC) was provided by DuPont Agricultural Chemicals Ltd.). Lufenuron (Match ${ }^{\circledR} 5 \%$ EC) was supplied by Syngenta.

\section{Bioassay studies:}

Toxicity of the formulated chlorantraniliprole $\left(\right.$ Coragen $^{\circledR} 20 \%$ SC) and lufenuron (Match ${ }^{\circledR} 5 \%$ EC) against $2^{\text {nd }}$ and $4^{\text {th }}$ instar larvae of $S$. littoralis laboratory strains was evaluated. Homogenous pieces of castor oil leaves were dipped in a series of chlorantraniliprole or lufenuron concentrations for $10 \mathrm{sec}$., held vertically to allow excess solution to drip off and dried at room temperature. Treated pieces of castor oil leaf were transferred to a plastic cups, and an appropriate and fixed number (10 larvae per cup) of starved larvae were added. Each concentration was replicated four times. Mortality percentages were recorded after 24, 48, 72, $96 \mathrm{hrs}$ of treatment. Mortality counts were recorded and corrected according to Abbott equation (Abbott, 1925) and subjected to probit analysis (Finney, 1971). 


\section{Biochemical studies}

In vivo effect of chlorantraniliprole and lufenuron on AST and ALT activities of $4^{\text {th }}$ instar larvae of $S$. littoralis (Lab. strain)

Tissue preparation: Starved $4^{\text {th }}$ instar larvae of $S$. littoralis laboratory strain were fed on castor oil leaves dipped in chlorantraniliprole and lufenuron solution at $1 / 10$ $L_{50}, 1 / 2 L_{50}$ and $L_{50}$. Larvae fed on untreated castor oil leaves were used as control. Suitable numbers of total larvae of each treatment were collected after 96 hrs post-treatment. These larvae were homogenized $(1: 10 \mathrm{w} / \mathrm{v})$ in glass distilled water $(\mathrm{pH}=7)$ using glass homogenizer. The homogenate was centrifuged at 5000 rpm for 30 min at 4을 $\mathrm{C}$ using IEC-CRU 5000 cooling centrifuge. The supernatant was used for the estimation of AST (Aspartate aminotransferase), and ALT (Alanine aminotransferase) activities.

Enzyme assay: Activity of both enzymes AST and ALT was measured according to the method of Reitman and Frankel (1957), using Diamond Diagnostic kit (Diamond Co. Egypt). In this method, $100 \mu$ l of enzyme source was added to $500 \mu \mathrm{l}$ of $100 \mathrm{mM}$ phosphate buffer of $\mathrm{pH}=7.2$ containing $80 \mathrm{mM}$ L-aspartate as a substrate for AST or $80 \mathrm{mM}$ D-L-alanine as a substrate for ALT, and $4 \mathrm{mM}$ óketoglutarate. This mixture was incubated for $30 \mathrm{~min}$ at $37^{\circ} \mathrm{C}$. After that, $500 \mu \mathrm{l}$ of developing color reagent (4 $\mathrm{mM} \mathrm{2,4-dinitrophenylhydrazine)} \mathrm{was} \mathrm{added} \mathrm{and} \mathrm{the}$ solution was incubated for $20 \mathrm{~min}$ at room temperature. Lastly, $5 \mathrm{ml}$ of $0.4 \mathrm{~N} \mathrm{NaOH}$ was added then mixed and left at room temperature for five min. An assay mixture without enzyme source was used as the blank and the absorption was measured at the wave length of $546 \mathrm{~nm}$ using spectrophotometer (Milton Roy Spectronic 601). AST and ALT specific activities were determined as IU/mg protein/hr and calculated as a percentage of control.

\section{In vivo effect of $S$. littoralis (Lab. strain) $4^{\text {th }}$ instar larvae ALP activity by chlorantraniliprole and lufenuron}

Tissue preparation: Starved laboratory strain $4^{\text {th }}$ instar larvae of $S$. littoralis were fed on castor oil leaves dipped in chlorantraniliprole and lufenuron solution at $1 / 10$ $\mathrm{LC}_{50}, 1 / 2 \mathrm{LC}_{50}$ and $\mathrm{LC}_{50}$ plus the untreated larvae which have been used as control. Midguts were collected, after $96 \mathrm{hrs}$ post-treatment, excised, repeatedly washed with ice-cold saline solution $(0.9 \% \mathrm{NaCl})$ to remove foodstuff. These midguts were homogenized $(1: 10 \mathrm{w} / \mathrm{v})$ in $100 \mathrm{mM}$ phosphate buffer $(\mathrm{pH}=9.8)$, using glass homogenizer. The homogenate was centrifuged at $5000 \mathrm{rpm}$ for $30 \mathrm{~min}$ at $4^{\circ} \mathrm{C}$ using IEC-CRU 5000 cooling centrifuge. The supernatant was used for ALP (alkaline phosphatases) activity estimation.

Enzyme assay: Activity of ALP was determined according to the method of Dgkc (1972), using Diamond Diagnostic kit (Diamond Co. Egypt). In this method, $20 \mu \mathrm{l}$ of the enzyme source was added to $1000 \mu \mathrm{l}$ of $0.9 \mathrm{M}$ diethanolamine buffer (pH 9.8) containing $0.6 \mathrm{mM}$ magnesium ions and $1 \mathrm{mM}$ p-nitrophenyl phosphate, then mixed in the cuvette, incubated for 30 seconds in the spectrophotometer (Milton Roy Spectronic 601), using a stopwatch simultaneously and the reading was done again after exactly 1, 2 and 3 minutes at $405 \mathrm{~nm}$. ALP specific activity was determined as $\mathrm{IU} / \mathrm{mg}$ protein/hr and calculated as a percent age of control. 
Statistical analysis: Data was subjected to analysis of variance (ANOVA) (CoStat Statistical Software, 1990). The standard deviation (SD) of four replications was calculated. Means were compared with each other using Student-Newman Keuls (SNK) test (LSD at $\mathrm{P}<0.05)$.

Insecticides relative potency was calculated as the following equation:

$$
\text { Relative potency }=\frac{L c_{50} \text { of the least effectiv e insecticide }}{L c_{90} \text { of the other insecticide }}
$$

\section{RESULTS:}

Toxicity of chlorantraniliprole and lufenuron against the $2^{\text {nd }}$ and $4^{\text {th }}$ larval instars of $S$. littoralis

Toxicity of chlorantraniliprole and lufenuron against the $2^{\text {nd }}$ and $4^{\text {th }}$ larval instars of $S$. littoralis by leaves dipping technique (mixing the insecticide with food) after different exposure times is shown in Tables 1 and 2 . Regarding the $2^{\text {nd }}$ instar larvae, chlorantraniliprole $\left(\mathrm{LC}_{50}=0.009,0.005\right.$ and $\left.0.003 \mathrm{mg} / \mathrm{l}\right)$ was approximately 234.33, 206.20 and 226.33 fold more toxic than lufenuron $\left(\mathrm{LC}_{50}=2.019,1.031\right.$ and $0.679 \mathrm{mg} / \mathrm{l}$ ) after 48, 72 and $96 \mathrm{hrs}$ post-treatment, respectively (Table 1).

Table (1): Toxicity of chlorantraniliprole and lufenuron against $2^{\text {nd }}$ instar larvae of S. littoralis after different exposure times

\begin{tabular}{|c|c|c|c|c|c|c|}
\hline Insecticide & $\begin{array}{l}\text { Exposure } \\
\text { time (hrs) }\end{array}$ & $\begin{array}{c}\mathrm{LC}_{50}(\mathrm{mg} / \mathrm{l}) \\
\text { (95\% CL) } \\
\text { (Lower-Upper) }\end{array}$ & $\begin{array}{c}\mathrm{LC}_{25}(\mathrm{mg} / \mathrm{l}) \\
\text { (95\% CL) } \\
\text { (Lower-Upper) }\end{array}$ & $\begin{array}{c}\mathrm{LC}_{10}(\mathrm{mg} / \mathrm{l}) \\
\text { (95\% CL) } \\
\text { (Lower-Upper) }\end{array}$ & Slope \pm SE & $\begin{array}{c}\text { Relative } \\
\text { potency at } \\
\text { LC }_{50} \text { level }\end{array}$ \\
\hline \multirow{3}{*}{ Chlorantraniliprole } & 48 & $\begin{array}{c}0.009 \\
(0.008-0.013)\end{array}$ & $\begin{array}{c}0.004 \\
(0.003-0.005)\end{array}$ & $\begin{array}{c}0.002 \\
(0.001-0.003)\end{array}$ & $1.84 \pm 0.27$ & 234.33 \\
\hline & 72 & $\begin{array}{c}0.005 \\
(0.005-0.006)\end{array}$ & $\begin{array}{c}0.002 \\
(0.002-0.003)\end{array}$ & $\begin{array}{c}0.001 \\
(0.001-0.002)\end{array}$ & $2.03 \pm 0.18$ & 206.20 \\
\hline & 96 & $\begin{array}{c}0.003 \\
(0.003-0.004)\end{array}$ & $\begin{array}{c}0.002 \\
(0.001-0.002)\end{array}$ & $\begin{array}{c}0.001 \\
(0.0005-0.009)\end{array}$ & $1.92 \pm 0.19$ & 226.33 \\
\hline \multirow{3}{*}{ Lufenuron } & 48 & $\begin{array}{c}2.109 \\
(1.806-2.471)\end{array}$ & $\begin{array}{c}0.886 \\
(0.682-1.073)\end{array}$ & $\begin{array}{c}0.406 \\
(0.274-0.540)\end{array}$ & $1.79 \pm 0.17$ & 1.00 \\
\hline & 72 & $\begin{array}{c}1.031 \\
(0.859-1.24)\end{array}$ & $\begin{array}{c}0.373 \\
(0.277-0.469)\end{array}$ & $\begin{array}{c}0.149 \\
(0.093-0.21)\end{array}$ & $1.53 \pm 0.15$ & 1.00 \\
\hline & 96 & $\begin{array}{c}0.679 \\
(0.599-0.809)\end{array}$ & $\begin{array}{c}0.255 \\
(0.183-0.327)\end{array}$ & $\begin{array}{c}0.106 \\
(0.064-0.152)\end{array}$ & $1.59 \pm 0.147$ & 1.00 \\
\hline
\end{tabular}

Table (2): Toxicity of chlorantraniliprole and lufenuron against $4^{\text {th }}$ instar larvae of S. littoralis after different exposure times

\begin{tabular}{|c|c|c|c|c|c|c|}
\hline Insecticide & $\begin{array}{l}\text { Exposure } \\
\text { time (hrs) }\end{array}$ & $\begin{array}{c}\text { LC50 (mg/l) } \\
\text { (95\% CL) } \\
\text { (Lower-Upper) }\end{array}$ & $\begin{array}{c}\text { LC25 (mg/l) } \\
\text { (95\% CL) } \\
\text { (Lower-Upper) }\end{array}$ & $\begin{array}{c}\text { LC10 (mg/l) } \\
\text { (95\% CL) } \\
\text { (Lower-Upper) } \\
\end{array}$ & Slope \pm SE & $\begin{array}{c}\text { Relative } \\
\text { potency at } \\
\text { LC50 level }\end{array}$ \\
\hline \multirow{3}{*}{ Chlorantraniliprole } & 48 & $\begin{array}{c}6.645 \\
(1.27-177.8)\end{array}$ & $\begin{array}{c}0.025 \\
(0.008-0.07)\end{array}$ & $\begin{array}{c}0.0002 \\
(0.0001-0.00025)\end{array}$ & $0.28 \pm 0.03$ & 2.01 \\
\hline & 72 & $\begin{array}{c}0.028 \\
(0.02-0.04)\end{array}$ & $\begin{array}{c}0.005 \\
(0.003-0.007)\end{array}$ & $\begin{array}{c}0.0009 \\
(0.0004-0.002)\end{array}$ & $0.87 \pm 0.08$ & 105.36 \\
\hline & 96 & $\begin{array}{c}0.006 \\
(0.005-0.008)\end{array}$ & $\begin{array}{c}0.001 \\
(0.001-0.002)\end{array}$ & $\begin{array}{c}0.0003 \\
(0.0001-0.0006)\end{array}$ & $0.99 \pm 0.1$ & 311.67 \\
\hline \multirow{3}{*}{ Lufenuron } & 48 & $\begin{array}{c}13.37 \\
(10.73-21.78)\end{array}$ & $\begin{array}{c}6.90 \\
(5.92-7.96)\end{array}$ & $\begin{array}{c}3.80 \\
(2.36-4.72)\end{array}$ & $2.35 \pm 0.50$ & 1.00 \\
\hline & 72 & $\begin{array}{c}2.95 \\
(2.55-3.39)\end{array}$ & $\begin{array}{c}1.35 \\
(1.04-1.64)\end{array}$ & $\begin{array}{c}0.667 \\
(0.442-0.889)\end{array}$ & $1.98 \pm 0.19$ & 1.00 \\
\hline & 96 & $\begin{array}{c}1.87 \\
(1.62-2.12)\end{array}$ & $\begin{array}{c}0.991 \\
(0.741-1.20)\end{array}$ & $\begin{array}{c}0.559 \\
(0.535-0.747)\end{array}$ & $2.45 \pm 0.303$ & 1.00 \\
\hline
\end{tabular}


Concerning the treated $4^{\text {th }}$ instar larvae, chlorantraniliprole $\left(\mathrm{LC}_{50}=6.645\right.$, 0.028 and $0.006 \mathrm{mg} / \mathrm{l}$ ) was approximately $2.01,105.36$ and 311.67 times more toxic than lufenuron $\left(\mathrm{LC}_{50}=13.37,2.95\right.$ and $\left.1.87 \mathrm{mg} / \mathrm{l}\right)$ after 48, 72 and $96 \mathrm{hrs}$ posttreatment, respectively (Table 2 ).

\section{In vivo effect of chlorantraniliprole and lufenuron on AST activity of $S$. littoralis $4^{\text {th }}$ instar larvae}

The in vivo effects of chlorantraniliprole and lufenuron on S. littoralis AST activity after different exposure times are presented in Tables 3 and 4 . It is clear that, the activity of AST is increased with the increase of chlorantraniliprole and lufenuron concentrations and as will as the increase of the exposure time. The AST activity reached to its highest levels after $96 \mathrm{hrs}$ of exposure, where it was $190.1 \%$ as compared to control at the concentration of $0.006 \mathrm{mg} / \mathrm{l}\left(\mathrm{LC}_{50}\right)$ of chlorantraniliprole (Table 3 ). In the case of lufenuron, AST reached to the highest activity (316.2\% as compared to control) after $96 \mathrm{hrs}$ at $1.870 \mathrm{mg} / \mathrm{l}$ (LC50) (Table 4).

\section{In vivo effect of chlorantraniliprole and lufenuron on ALT activity of $S$. littoralis $4^{\text {th }}$ instar larvae}

In vivo effects of chlorantraniliprole and lufenuron on ALT activity of $S$. littoralis $4^{\text {th }}$ instar larvae after different exposure times are presented in Tables 5 and 6 . It is clear that the exposure of CLW $4^{\text {th }}$ instar larvae to different tested concentrations of chlorantraniliprole or lufenuron after different exposure times resulted in the increase of the ALT activity. When the $4^{\text {th }}$ instar $S$. littoralis larvae were exposed to chlorantraniliprole at $0.006 \mathrm{mg} / \mathrm{l}$ for an exposure period of $96 \mathrm{hrs}$, ALT activity was $173.4 \%$ as a percentage of control (Table 5). The activity of ALT was $221.1 \%$ as that of control $(100 \%)$ when CLW $4^{\text {th }}$ instar larvae were exposed to lufenuron at concentrations of $1.870 \mathrm{mg} / \mathrm{l}$ (Table 6).

In vivo inhibition of alkaline phosphatase (ALP) activity of S. littoralis $4^{\text {th }}$ instar larvae by chlorantraniliprole and lufenuron at different exposure times

In vivo inhibition of ALP activity within treated $S$. littoralis $4^{\text {th }}$ instar larvae by chlorantraniliprole after different exposure times was investigated (Table 7). When $S$. littoralis larvae were treated with chlorantraniliprole at concentrations of 0.0006 , 0.003 and $0.006 \mathrm{mg} / \mathrm{l}$, ALP activity was $92.7,81.8$, and $68.2 \%$ as a percentage of control (100\%), respectively after $48 \mathrm{hrs}$ of exposure. ALP activity after $72 \mathrm{hrs}$ of exposure was $78.1,61.6$, and $50.5 \%$ of that of control at the same concentrations, respectively. After $96 \mathrm{hrs}$ of exposure, the ALP activity was $68.2,59.5$ and $47.3 \%$ of that of control at the same concentrations, respectively. The in vivo inhibition of ALP activity of $S$. littoralis $4^{\text {th }}$ instar larvae treated with lufenuron was also investigated after different exposure times (Table 8). 
Table (3): In vivo effect of chlorantraniliprole on the AST activity of S. littoralis $4^{\text {th }}$ instar larvae after different exposure times

\begin{tabular}{|c|c|c|c|c|c|c|}
\hline \multirow{3}{*}{$\begin{array}{c}\text { Insecticide } \\
\text { concentration } \\
(\mathrm{mg} / \mathrm{l})\end{array}$} & \multicolumn{6}{|c|}{ Activity after different exposure times (hrs) } \\
\hline & \multicolumn{2}{|c|}{48} & \multicolumn{2}{|c|}{72} & \multicolumn{2}{|c|}{96} \\
\hline & $S . A^{*} \pm S D$ & $\begin{array}{c}\text { Activity } \\
(\%) \pm \text { SD }\end{array}$ & $S . A \pm S D$ & $\begin{array}{c}\text { Activity } \\
(\%) \pm \text { SD }\end{array}$ & $S . A \pm S D$ & $\begin{array}{c}\text { Activity } \\
(\%) \pm \text { SD }\end{array}$ \\
\hline 0.0000 (control) & $670.9^{c} \pm 12.9$ & $100.0 \pm 1.92$ & $580.4^{d} \pm 16.1$ & $100.0 \pm 2.77$ & $571.7^{d} \pm 11.2$ & $100.0 \pm 1.96$ \\
\hline 0.0006 & $775.2^{\mathrm{b}} \pm 22.3$ & $115.5 \pm 3.32$ & $687.7^{c} \pm 26.6$ & $118.5 \pm 4.58$ & $608.0^{c} \pm 21.0$ & $106.3 \pm 3.67$ \\
\hline 0.0030 & $803.7^{b} \pm 36.5$ & $119.8 \pm 5.44$ & $742.0^{\mathrm{b}} \pm 36.2$ & $127.8 \pm 6.23$ & $686.7^{b} \pm 26.3$ & $120.1 \pm 4.60$ \\
\hline 0.0060 & $843.4^{a} \pm 44.7$ & $125.7 \pm 6.66$ & $823.8^{a} \pm 41.3$ & $141.9 \pm 7.11$ & $1086.8^{a} \pm 30.9$ & $190.1 \pm 5.40$ \\
\hline
\end{tabular}

${ }^{*} \mathrm{~S} . \mathrm{A}=$ Specific activity (IU / mg protein / hr). Numbers within the same column followed by the same letter(s) are not significantly different according to Student-Newman Keuls (SNK) test (LSD 0.05$)$.

Table (4): In vivo effect of lufenuron on the AST activity of S. littoralis $4^{\text {th }}$ instar larvae after different exposure times

\begin{tabular}{|c|c|c|c|c|c|c|}
\hline \multirow{3}{*}{$\begin{array}{l}\text { Insecticide } \\
\text { concentration } \\
(\mathrm{mg} / \mathrm{l})\end{array}$} & \multicolumn{6}{|c|}{ Activity after different exposure times (hrs) } \\
\hline & \multicolumn{2}{|c|}{48} & \multicolumn{2}{|c|}{72} & \multicolumn{2}{|c|}{96} \\
\hline & $S . A^{\star} \pm S D$ & $\begin{array}{c}\text { Activity } \\
(\%) \pm \text { SD }\end{array}$ & $S . A \pm S D$ & $\begin{array}{c}\text { Activity } \\
(\%) \pm \text { SD }\end{array}$ & $S . A \pm S D$ & $\begin{array}{c}\text { Activity } \\
(\%) \pm \text { SD }\end{array}$ \\
\hline 0.000 (control) & $860.9 d \pm 32.4$ & $100.0 \pm 3.8$ & $490.6 c \pm 36.3$ & $100.0 \pm 7.4$ & $381.7 \mathrm{~d} \pm 11.2$ & $100.0 \pm 2.9$ \\
\hline 0.187 & $885.2 c \pm 52.5$ & $102.8 \pm 6.1$ & $497.8 \mathrm{c} \pm 6.7$ & $101.5 \pm 1.4$ & $468.0 \mathrm{c} \pm 0.0$ & $122.6 \pm 0.0$ \\
\hline 0.935 & $981.7 b \pm 26.7$ & $114.0 \pm 3.1$ & $552.1 b \pm 46.2$ & $112.5 \pm 9.4$ & $596.7 b \pm 6.3$ & $156.3 \pm 1.7$ \\
\hline 1.870 & $1153.4 a \pm 34.3$ & $134.0 \pm 4.0$ & $654.9 a \pm 51.3$ & $133.5 \pm 10.5$ & $1206.9 a \pm 30.9$ & $316.2 \pm 8.1$ \\
\hline
\end{tabular}

$\star \bar{S} . \mathrm{A}=$ Specific activity (IU / mg protein / hr). Numbers within the same column followed by the same letter are not significantly different according to Student-Newman Keuls (SNK) test $\left(\mathrm{LSD}_{0.05}\right)$.

Table (5): In vivo effect of chlorantraniliprole on the ALT activity of S. littoralis $4^{\text {th }}$ instar larvae after different exposure times

\begin{tabular}{ccccccc}
\hline \multirow{2}{*}{$\begin{array}{c}\text { Insecticide } \\
\text { concentration } \\
\text { (mg/l) }\end{array}$} & \multicolumn{6}{c}{ Activity after different exposure times (hrs) } \\
\cline { 2 - 7 } & $\mathrm{S} . \mathrm{A}^{\star} \pm \mathrm{SD}$ & $\begin{array}{c}\text { Activity } \\
(\%) \pm \mathrm{SD}\end{array}$ & $\mathrm{S} . \mathrm{A} \pm \mathrm{SD}$ & $\begin{array}{c}\text { Activity } \\
(\%) \pm \text { SD }\end{array}$ & S.A \pm SD & $\begin{array}{c}\text { Activity } \\
(\%) \pm \text { SD }\end{array}$ \\
\hline 0.0000 (control) & $465.1 \mathrm{c} \pm 27.4$ & $100.0 \pm 5.9$ & $414.5 \mathrm{~d} \pm 18.7$ & $100.0 \pm 4.6$ & $381.8 \mathrm{~d} \pm 22.0$ & $100.0 \pm 5.8$ \\
0.0006 & $592.4 \mathrm{~b} \pm 19.8$ & $127.4 \pm 4.3$ & $510.8 \mathrm{c} \pm 10.5$ & $126.9 \pm 2.6$ & $451.9 \mathrm{c} \pm 15.4$ & $118.4 \pm 4.0$ \\
0.0030 & $622.5 \mathrm{~b} \pm 12.5$ & $133.9 \pm 2.9$ & $600.6 \mathrm{~b} \pm 9.7$ & $118.9 \pm 1.9$ & $520.5 \mathrm{~b} \pm 9.6$ & $136.4 \pm 2.5$ \\
0.0060 & $805.1 \mathrm{a} \pm 9.2$ & $173.2 \pm 2.0$ & $746.5 \mathrm{a} \pm 3.2$ & $147.8 \pm 0.6$ & $661.7 \mathrm{a} \pm 9.4$ & $173.4 \pm 2.5$
\end{tabular}

$\star \overline{\mathrm{S}} . \mathrm{A}=$ Specific activity (IU / $\mathrm{mg}$ protein / hr). Numbers within the same column followed by the same letter are not significantly different according to Student-Newman Keuls (SNK) test (LSD 0.05$)$.

Table (6): In vivo effect of lufenuron on the ALT activity of S. littoralis $4^{\text {th }}$ instar larvae after different exposure times

\begin{tabular}{|c|c|c|c|c|c|c|}
\hline \multirow{3}{*}{$\begin{array}{c}\text { Insecticide } \\
\text { concentration } \\
(\mathrm{mg} / \mathrm{l})\end{array}$} & \multicolumn{6}{|c|}{ Activity after different exposure times (hr) } \\
\hline & \multicolumn{2}{|c|}{48} & \multicolumn{2}{|c|}{72} & \multicolumn{2}{|c|}{96} \\
\hline & $S . A^{*} \pm S D$ & $\begin{array}{c}\text { Activity } \\
(\%) \pm \text { SD }\end{array}$ & $S . A \pm S D$ & $\begin{array}{l}\text { Activity } \\
(\%) \pm \text { SD }\end{array}$ & $S . A \pm S D$ & $\begin{array}{c}\text { Activity } \\
(\%) \pm \text { SD }\end{array}$ \\
\hline 0.000 (control) & $555.7 \mathrm{c} \pm 33.2$ & $100.0 \pm 6.0$ & $518.0 \mathrm{~d} \pm 38.7$ & $100.0 \pm 7.5$ & $431.5 d \pm 32.3$ & $100.0 \pm 7.5$ \\
\hline 0.187 & $765.1 b \pm 29.8$ & $137.7 \pm 5.4$ & $602.1 \mathrm{c} \pm 30.5$ & $116.2 \pm 5.9$ & $593.2 c \pm 25.6$ & $137.5 \pm 5.9$ \\
\hline 0.935 & $799.5 b \pm 22.5$ & $143.9 \pm 4.0$ & $747.1 b \pm 29.7$ & $144.2 \pm 5.7$ & $671.6 b \pm 19.9$ & $155.6 \pm 4.6$ \\
\hline 1.870 & $878.2 \mathrm{a} \pm 19.2$ & $158.0 \pm 3.5$ & $899.5 a \pm 13.2$ & $173.6 \pm 2.5$ & $953.9 \mathrm{a} \pm 11.1$ & $221.1 \pm 2.6$ \\
\hline
\end{tabular}

${ }^{*} \mathrm{~S} . \mathrm{A}=$ Specific activity (IU / mg protein / hr). Numbers within the same column followed by the same letter are not significantly different according to Student-Newman Keuls (SNK) test $\left(\mathrm{LSD}_{0.05}\right)$. 
Table (7): In vivo effect of chlorantraniliprole on the ALP activity of S. littoralis $4^{\text {th }}$ instar larvae after different exposure times

\begin{tabular}{|c|c|c|c|c|c|c|}
\hline \multirow{3}{*}{$\begin{array}{c}\text { Insecticide } \\
\text { concentration } \\
(\mathrm{mg} / \mathrm{l})\end{array}$} & \multicolumn{6}{|c|}{ Activity after different exposure times (hr) } \\
\hline & \multicolumn{2}{|c|}{48} & \multicolumn{2}{|c|}{72} & \multicolumn{2}{|c|}{96} \\
\hline & $S . A \pm S D$ & $\begin{array}{c}\text { Activity } \\
(\%) \pm \text { SD }\end{array}$ & $S . A \pm S D$ & $\begin{array}{c}\text { Activity } \\
(\%) \pm \text { SD }\end{array}$ & $S . A \pm S D$ & $\begin{array}{c}\text { Activity } \\
(\%) \pm \text { SD }\end{array}$ \\
\hline 0.0000 (control) & $943.9 \mathrm{a} \pm 22.9$ & $100.0 \pm 2.4$ & 880.4 a \pm 26.1 & $100.0 \pm 3.0$ & $817.7 a \pm 11.2$ & $100.0 \pm 1.4$ \\
\hline 0.0006 & $875.2 b \pm 42.3$ & $92.7 \pm 4.5$ & $687.7 b \pm 6.6$ & $78.1 \pm 0.7$ & $558.0 b \pm 0.0$ & $68.2 \pm 0.0$ \\
\hline 0.0030 & $771.7 c \pm 16.5$ & $81.8 \pm 1.7$ & $542.0 \mathrm{c} \pm 36.2$ & $61.6 \pm 4.1$ & $486.7 c \pm 6.3$ & $59.5 \pm 0.8$ \\
\hline 0.0060 & $643.4 d \pm 24.7$ & $68.2 \pm 2.6$ & $444.8 d \pm 41.3$ & $50.5 \pm 4.7$ & $386.8 d \pm 30.9$ & $47.3 \pm 3.8$ \\
\hline
\end{tabular}

${ }^{*} \mathrm{~S} . \mathrm{A}=$ Specific activity (IU / mg protein / hr). Numbers within the same column followed by the same letter (s) are not significantly different according to Student-Newman Keuls (SNK) test (LSD $\left.{ }_{0.05}\right)$.

Table (8): In vivo effect of lufenuron on the ALP activity of S. littoralis $4^{\text {th }}$ instar larvae after different exposure times.

\begin{tabular}{|c|c|c|c|c|c|c|}
\hline \multirow{3}{*}{$\begin{array}{c}\text { Insecticide } \\
\text { concentration ( } \\
\mathrm{mg} / \mathrm{l} \text { ) }\end{array}$} & \multicolumn{6}{|c|}{ Activity after different exposure times (hr) } \\
\hline & \multicolumn{2}{|c|}{48} & \multicolumn{2}{|c|}{72} & \multicolumn{2}{|c|}{96} \\
\hline & $S . A^{*} \pm S D$ & $\begin{array}{c}\text { Activity (\%) } \\
\pm \text { SD }\end{array}$ & S.A \pm SD & $\begin{array}{l}\text { Activity } \\
(\%) \pm \text { SD }\end{array}$ & S.A \pm SD & $\begin{array}{l}\text { Activity } \\
(\%) \pm \text { SD }\end{array}$ \\
\hline 0.000 (control) & $1172.4 \mathrm{a} \pm 8.7$ & $100.0 \pm 0.7$ & $1048.8 a \pm 16.6$ & $100.0 \pm 1.6$ & $1086.6 a \pm 1.2$ & $100.0 \pm 0.1$ \\
\hline 0.187 & $672.0 \mathrm{~b} \pm 26.5$ & $77.03 \pm 3.0$ & $681.7 \mathrm{~b} \pm 5.6$ & $65.0 \pm 0.5$ & $644.0 \mathrm{~b} \pm 2.0$ & $59.3 \pm 0.02$ \\
\hline 0.935 & $605.7 c \pm 16.9$ & $69.43 \pm 1.9$ & $382.1 \mathrm{c} \pm 26.5$ & $36.4 \pm 2.5$ & $388.7 c \pm 5.3$ & $35.8 \pm 0.49$ \\
\hline 1.870 & $477.7 d \pm 14.2$ & $54.76 \pm 1.6$ & $106.4 d \pm 31.3$ & $10.1 \pm 3.0$ & $165.2 \mathrm{~d} \pm 19.9$ & $15.2 \pm 1.83$ \\
\hline
\end{tabular}

${ }^{*} \mathrm{~S} . \mathrm{A}=$ Specific activity (IU / mg protein / hr). Numbers within the same column followed by the same letter are not significantly different according to Student-Newman Keuls (SNK) test $\left(\mathrm{LSD}_{0.05}\right)$.

When S. littoralis larvae were treated with lufenuron at concentrations of $0.187,0.935$, and $1.870 \mathrm{mg} / \mathrm{l}$, the ALP activity was $77.03,69.43$ and $54.76 \%$ of that of control, respectively, after 48 hrs of exposure. ALP activity after 72 hrs of exposure was $65.0,36.4$, and $10.1 \%$ (as percentages of control), at the same concentrations, respectively. After 96 hrs of exposure, ALP activity was 59.3, 35.8, and $15.2 \%$ of that of control at the same concentrations, respectively. From these data it could be concluded that the inhibition of ALP by chlorantraniliprole and lufenuron is concentration and time dependent.

\section{DISCUSSION}

Many insect pests present an ongoing battle between the grower's ability to control the pest and the pest's ability to resist the available control methods. The discovery of new, novel insect control agents for use against insect pests has served as a focal point for insecticide research for more than five decades, since the insects were actually conquered for the first time about 55 years ago. Because there are several problems resulted from the intensive use of synthetic insecticides, trends in pest management now are emphasis on methods of controlling insect pests apart from it. Chlorantraniliprole is an example for searching about new compounds with high activity in insect control and low ecotoxicity.

In the present study, experiments were conducted to evaluate the susceptibility of $S$. littoralis to chlorantraniliprole and lufenuron. The carried out bioassay enhances the understanding of differential toxicity of these compounds 
against the insect. From the data obtained in this study, it is obvious that chlorantraniliprole exert high toxicity against the $2^{\text {nd }}$ and $4^{\text {th }}$ larval instars of $S$. littoralis. The toxicity is increased as the concentration rates and exposure time increased while decreased as the insect instars increased. Temple et al. (2009) stated that Rynaxypyr ${ }^{\circledR}$ (chlorantraniliprole) demonstrated very good activity at relatively low rates against all three tested major caterpillar pests of cotton in their study, including tobacco budworm, bollworm, and fall armyworm. Because of the high insecticidal activity of Rynaxypyr ${ }^{\circledR}$ (chlorantraniliprole), Lahm et al. (2007) mentioned that Rynaxypyr ${ }^{\circledR}$ (chlorantraniliprole) could be an excellent option for resistance management strategies as an additional class of chemistry and mode of action for management of lepidopteran pests in cotton. Also, they declared that the high degree of mammalian safety, relatively low use rates compared to standard insecticides (pyrethroids, organophosphates, and carbamates), long residual properties, and broad spectrum of activity against lepidopteran pests will make chlorantraniliprole an excellent control option in an overall integrated pest management system.

Results obtained with both AST and ALT enzymes revealed that the exposure of $S$. littoralis $4^{\text {th }}$ instar larvae to different concentrations of chlorantraniliprole and lufenuron at different exposure times resulted in an increase in the activity levels of these enzymes. The determined changes in the AST and ALT activity levels in the $4^{\text {th }}$ instar larvae of $S$. littoralis following different periods of sub-lethal and lethal chlorantraniliprole and lufenuron exposure suggested that $S$. littoralis exhibited adaptive elevation in the activity levels of both the aminotransferase enzymes, thereby probably aiding gluconeogenesis through transamination of glucogenic amino acids to meet the energy demand under chlorantraniliprole and lufenuron toxicity. These data is in accordance with the arrived at results by other authors. Ramaswamy et al. (1999) reported that the activity levels of AST and ALT enzymes were elevated when the fish Sarotherodon mossambicus had been exposed to sub-lethal $(3 \mathrm{mg} / \mathrm{l})$ and lethal $(25 \mathrm{mg} / \mathrm{l})$ concentrations of the carbamate insecticide carbaryl. Radwan et al. (1992) reported that the possible mechanism involved in the elevation of AST and ALT levels may be due to the tissue damage, as a result of the increased synthesis and/or the decreased metabolism of both enzymes.

Alkaline phosphatases (LPs) are classically described as homodimeric nonspecific metalloenzymes which catalyze phosphomonesterase reactions (Trowsdale et al., 1990). Phosphatases have been included in the list of detoxifying enzymes of insecticides; mostly of organophosphorus (Oppenoorth, 1985), however, fenvalerate and cypermethrin resistant larvae of Helicoverpa armigera showed higher activities of esterases, phosphatases and methyl paraoxon hydrolase compared with susceptible larvae (Srinivas et al., 2003). In the present study, chlorantraniliprole and lufenuron inhibited ALP activity. Based on the toxicity of chlorantraniliprole and lufenuron against the laboratory strain and the in vivo inhibition of ALP activity, chlorantraniliprole and lufenuron could be usefully incorporated and used for developing a more effective management program for $S$. littoralis. 


\section{REFERENCES}

Abbott, W. S. (1925). A method for computing the effectiveness of an insecticide. J. Econ. Entomol., 18: 265-267.

Abo Elghar, G. E., Z. A. Elbermawy, A. G. Yousef and H. K. Abd Elhady (2005). Monitoring and characterization of insecticide resistance in the cotton leafworm, Spodoptera littoralis (Boisd.) (Lepidoptera: Noctuidae). J. AsiaPac. Entomol., 8: 397-410.

Abo-El-Ghar, M. R., M. E. Nassar, M. R. Riskalla and S. F. Abd-El-Ghafar (1986). Rate of development of resistance and pattern of cross-resistance in fenvalerate and decamethrin-resistant strains of Spodoptera littoralis. Agric. Res. Rev., 61: 141-145.

Abou-Taleb, H. K. (2010). Differential toxicity of some insecticides against egg and larval stages of cotton leafworm and role of two detoxification enzymes. Alex. Sci. Exch. J., 31: $356-364$.

Bentley, K. S., J. L. Fletcher and M. D. Woodward (2010). Chlorantraniliprole: an insecticide of the anthranilic diamide class. In: Hayes' Handbook of Pesticide Toxicology. Krieger, R. (Ed.), Academic Press, London. UK, pp. 2232-2242.

Cao, G., Q. Lu, L. Zhang, F. Guo, G. Liang, K. Wu and K. G. Wyckhuys (2010). Toxicity of chlorantraniliprole to CryAc-susceptible and resistant strain of Helicoverpa armigera. Pestic. Biochem. Physiol., 98:99-103.

CoStat Statistical Software (1990). Microcomputer program analysis version 4.20, CoHort Software, Berkeley, CA., USA

Dgkc (1972). Empfehlugen der Deutschen Gesellschaft fur Klinische $\underline{\text { Chemie. }}$ Standard-method zur bestimmung der aktivitat der alkalischen phosphatase (AP). Z. Klin. Chem. Klin Biochem., 182: 192.

Eldefrawi, M. E., A. Toppozada, N. Mansour and M. Zeid (1964). Toxicological studies on the Egyptian cotton leafworm, Prodenia litura. I. Susceptibility of different larval instars of Prodenia to insecticides. J. Econ. Entomol., 57: 591593.

Finney, D. J. (1971). Probit analysis, Cambridge Univ. Press, Cambridge.

Hannig, G. T., M. Ziegler and P. G. Marcon (2009). Feeding cessation effects of chlorantraniliprole, a new anthranilic diamide insecticide, in comparison with several insecticides in distinct chemical classes and mode-of-action groups. Pest Manag. Sci., 65: 969-974.

Hatem, A. E., H. B. Homam, R. A. M. Amer, S. S. M. Abdel-Samad, H. A. Saleh and A. I. Hussien (2009). Synergistic activity of several acids in binary mixtures with synthetic insecticides on Spodoptera littoralis (Boisduval). Boletin de Sanidad Vegetal Plagas., 35:533-542.

Lahm, G. P., T. P. Selby, J. H. Freudenberger, T. M. Stevenson, B. J. Myers, G. Seburyamo, B. K. Smith, L. Flexner, C. E. Clark and D. Cordova (2005). Insecticidal anthranilic diamides: a new class of potent ryanodine receptor activators. Bioorg. Med. Chem. Lett., 15:4898-4906.

Lahm, G. P., T. M. Stevenson, T. P. Selby, J. H. Freudenberger, D. Cordova, L. Flexner, C. A. Bellin, C. M. Dubas, B. K. Smith, K. A. Hughes, G. J. Hollingshaus, C. E. Clark and E. A. Benner (2007). Rynaxypyr: a new insecticidal anthranilic diamide that acts as a potent and selective ryanodine receptor activator. Bioorg. Med. Chem. Lett., 17: 6274-6279. 
Lahm, G. P., D. Cordova and J.D. Barry (2009). New and selective ryanodine receptor activators for insect control. Bioorg. Med. Chem. Lett., 17:41274133.

Larson, J. L., C. T. Redmond and D. A. Potter (2012). Comparative impact of an anthranilic diamide and other insecticidal chemistries on beneficial invertebrates and ecosystem services in turfgrass. Pest Manag. Sci., 68:740748.

Oppenoorth, F. J. (1985). Biochemistry and Genetics of Insecticide Resistance. In: Kerkut, G. A. and L. I. Gillbert [Eds.] Comprehensive Insect Physiol. Biochem. Pharmacol., 12:731-773.

Radwan, M. A., H. B. EL-Wakil and K. A. Osman (1992). Toxicity and biochemical impact of certain oxime carbamate pesticides against terrestrial snail, Theba pisana (Müller). J. Environ. Sci. Health Part B : Pesticides, Food contamin. Agric. Wastes, 27(6):759-773.

Ramaswamy, M., P. Thangavel and N. P. Selvam (1999). Glutamic oxaloacetic transaminase (GOT) and glutamic pyruvic transaminase (GPT) enzyme activities in different tissues of Sarotherodon mossambicus (Peters) exposed to a carbamate pesticide, carbaryl. Pest. Sci., 55(12): 1217-1221.

Reitman, S. and S. Frankel (1957). A colorimetric method for the determination of serum glutamate oxaloacetate and glutamate puruvate transaminases. Amer. J. Ch. Pathol., 28:56-63.

Sattelle, D. B., D. Cordova and T. R. Cheek (2008). Insect ryanodine receptors: molecular targets for novel pest control chemicals. Invert. Neurosci., 8:107119.

Sial, A. A., J. F. Brunner and M. D. Doerr (2010). Susceptibility of Choristoneura rosaceana (Lepidoptera: Tortricidae) to two new reduced-risk insecticides. J. Econ. Entomol., 103:140-146.

Srinivas, R., S. S. Udikeri, S. K. Jayalakshmi and K. Sreeramulu (2003). Identification of factors responsible for insecticide resistance in Helicoverpa armigera (Hubner). resist. Pest Manag. Newl., 13 (1): 59-64.

Temple, J. H., P. L. Pommireddy, D. R. Cook, P. Marçon and B. R. Leonard (2009). Susceptibility of selected Lepidopteran pests to Rynaxypyr ${ }^{\circledR}$, a novel insecticide. Cotton Sci., 13:23-31.

Trowsdale, J., D. Martin, D. Bicknell and I. Campbell (1990). Alkaline phosphatases. Biochem. Soc. Trans., 18:178-180.

Wang, X. L., X.Y. Li, A. D. Shen and Y. D. Wu (2010). Baseline susceptibility of diamondback moth (Lepidoptera: Plutellidae) to chlorantraniliprole in China. J. Econ. Entomol., 103:843-848. 
الملخص العربي

سنشاط إنزيمات الكلورانترانيبرول واللوفنيرون ضد يرقات دودة ورق القطن وعلاقتها بتأثيرها على أمينوترانسفيريز والألانين أمينوترانسفيريز والأكالين فوسفاتيز

عبدالقتاح سيد عبدالكريم سعد' ، السبد حسن محمد تايب' ، وفاء حجازي '، ،

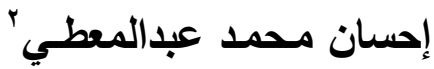

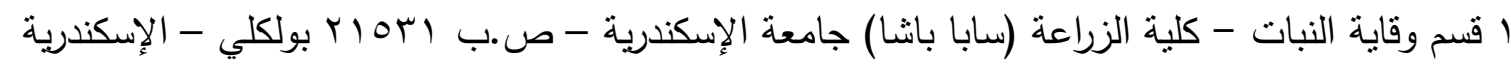

ب قسم إختبارات مبيدات القطن - معهد بحوث وقاية النباتات- مركز البحوث الزراعية - الدقي - الجيزة- مصر بالإن

نم دراسة سمية مبيد حشرى من مجموعة الأنثرانيليك ثنائية الأميد (كلورانترانيبرول) ومبيد حشرى من مجموعة مثنطات

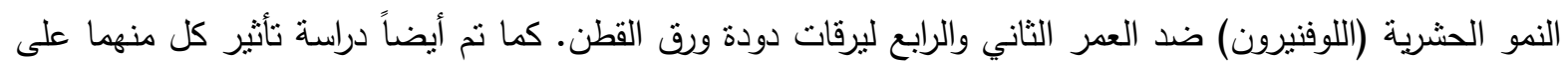

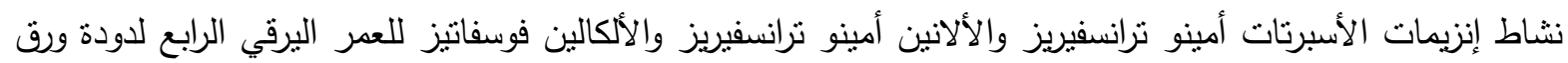
القطن. وقد أظهرت نتائج سمية المركبات المختبرة على يرقات العمر الثاني لدودة ورق القطن أن أن الكلورانترانييرول

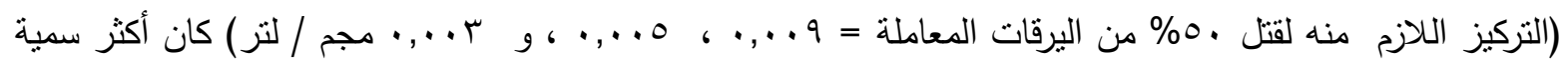

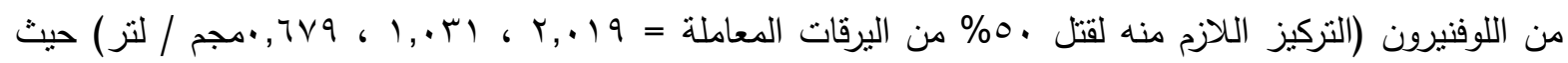

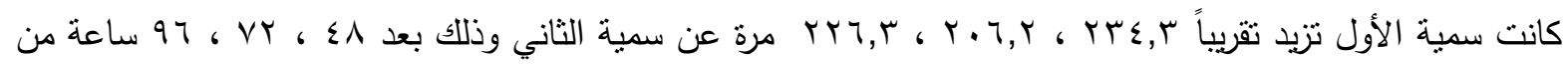

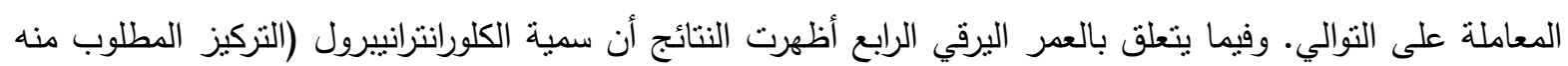

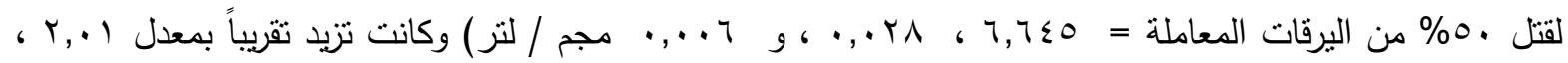

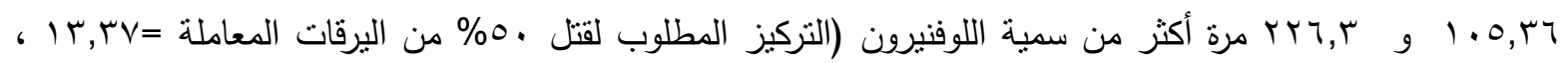

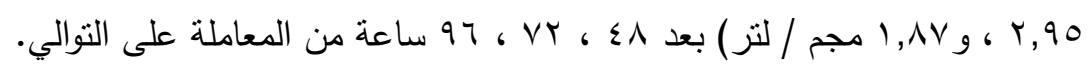

وقد أدى كل من الكلورانترانييرول واللوفنيرون عند التركيزات المختبرة إلى زيادة نشاط انزيمي الأسبرتات

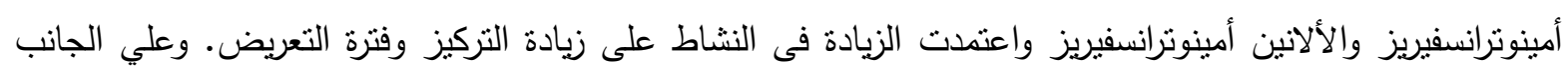

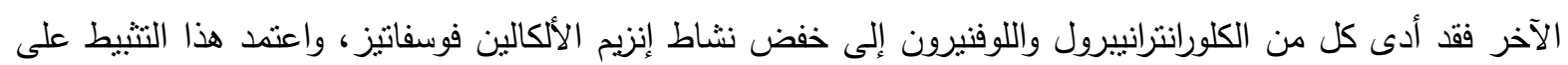
التركيز ووقت التعرض للمبيد.

وبالتالى بناءاً على النتائج التى تم التوصل إليها فى هذه الدراسة يمكن التوصية بإستخدام كل من الكلورانترانيبرول

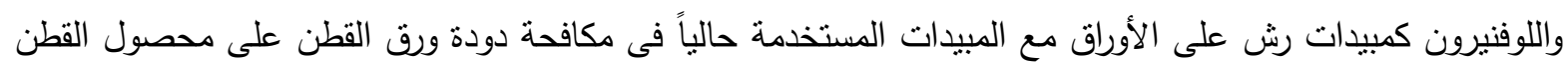
فى الحقل. 
